this same stratigraphical level a few mineralized nodules show complex admixtures of granular or massive celestite and small platy crystals of barytes.

In the upper half of the section several counts have revealed an average of 60 to 80 of these celestite nodules or geodes to the cubic metre. Local variations in their frequency, both along the general direction of the strike and in depth, are apparent, but these are not sufficiently consistent to suggest limits to the extent of their occurrence.

This new discovery of celestite nodules or geodes within a few metres of the surface is, perhaps, of palaeogeographical significance. It is a possible pointer to the likely existence of a former cover of Keuper Marl, maybe a hundred metres thick. The nodules are in effect pseudomorphs of former dolomitic pebbles or fragments, and it would appear that they were derived by metasomatism associated with descending solutions. Unfortunately, along the full length of the South Crop of the South Wales coalfield within the northern sections of the Vale of Glamorgan, exposures of Keuper Marl, as distinct from the Dolomitic Conglomerate, are very limited, and one is unable to determine whether the former shows occurrences of celestine on a larger scale, possibly in crudely bedded form as near Yate in Gloucestershire.

\title{
WELSH OFFICE,
}

SUMMTT HOUSE,

WINDSOR PLACE, CARDIFF.

25th January, 1968.

Trevor M. Thomas.

\section{JOINT AND FAULT PATTERNS IN NORTH-EAST TASMANIA}

Sir,-The detailed work of Williams (1967) at Dalrymple Hill, north-east Tasmania, has focused interest on the persistence or re-activation of stress fields that cause jointing and faulting. He has shown that:-

(i) Patterns of joints in Mathinna Beds differ from those in Permian rocks (op. cit., Figs. 4 and 5), and that a large number of joints are usually disposed at 90 degrees to the local fold axis (op. cit., p. 251).

(ii) Joints in the Permian rocks may be correlated with similarly orientated normal faults (op. cit., p. 244).

(iii) Joints in the Permian rocks and in the late Devonian granite yield similar patterns when plotted and contoured on a Lambert projection (op. cit., p. 249).

(iv) The three steep sets of joints in the granite are of similar trends to faults affecting Permian rocks (op. cit., p. 249).

Williams concluded from the foregoing items that (op. cit., p. 251) "No joints in the Siluro-Devonian beds can be attributed to the post-Permian faulting ...", the absence of fractures related to those of the Permian beds being "due to the anisotropy of the Mathinna rocks", that (op. cit., p. 249) "stress fields identical in orientation to those that caused the joints of the Permian rocks also caused those of the granite ", and that (op. cit., p. 251) "faults which dislocate the Permian rocks may have been established earlier and affected the granite before Permian times, resulting in joints of a similar pattern to those in the Permian rocks but of a different age ".

The geology of the Pipers River Quadrangle (Marshall et al., 1965) north-east Tasmania, in many ways approximates that at Dalrymple Hill (Williams, 1967). In the east of the area the late Devonian Scottsdale Batholith (McDougall \& Leggo, 1965) intrudes folded Siluro-Devonian Mathinna Beds, whilst in the west Permo-Triassic rocks unconformably overlie the Mathinna Beds and are intruded by a Jurassic dolerite sheet. A geometric analysis by Marshall (in press) of jointing and folding in the Quadrangle has considerable bearing on the conclusions of Williams (1967). The more pertinent aspects of the results will now be given.

(i) A majority of joints in the Mathinna Beds are approximately at right angles to the local and regionally-defined fold axes. Such a relationship is common in areas of statistically-cylindrical flattened flexural folding.

(ii) The joint pattern in the granodiorite is undistinguishable from Fig. $5 d$ of Williams (1967, p. 248). It is therefore constant over a distance of $64 \mathrm{~km}$ (40 miles) and in a really distinct but coeval granitic masses (McDougall \& Leggo, 1965). 
(iii) Joints and faults affecting the Permo-Triassic rocks are of similar orientation and are possibly cogenetic. It is probable that they post-date the known Jurassic since the major movement on faults in this quadrangle and in the one to the south (Longman, 1966) was post-dolerite intrusion and pre-Tertiary sedimentation.

(iv) The joint and fault sets of (iii) correspond to the vertical joint sets in the granodiorite. Of these trends the predominating ones approximate parallelism with the dip and strike of the Permian strata and the planar anisotropy of the Mathinna Beds cleavage.

(v) Tertiary basalt extrusions were probably related to activity on north-northwestward trending fault-lines.

It is apparent that, as found by Williams (1967), the post-triassic and most probably post-Jurassic joint pattern approximates that of the late Devonian granodiorite, both in turn being similar to the fault pattern in the Permo-Triassic and Jurassic rocks. Since these relationships are unlikely to be fortuitous it is proposed that :-

(i) They were the product of probably post-Jurassic stress fields. The work cited by Williams (1967, p. 251) would appear to negate this at Dalrymple Hill, whilst joint-bounded granodiorite blocks in basal Permian conglomerate (Marshall, in press) is opposed to this possibility in the Pipers River Quadrangle.

(ii) They reflect re-activation of stress fields and/or over-riding controls of the planes of failure that might tolerate a variation of perhaps 20 or 30 degrees in the orientation of the principal stress axes. This is in keeping with the tectonic history of the period, and the outbreak of Tertiary vulcanicity suggests a re-activated stress field.

This second proposal is favoured as an explanation of relationships in the Pipers River Quadrangle. It is tentatively suggested that such early formed features as the planar anisotropy of the steeply dipping cleavage in the Mathinna rocks could have been one of the controls envisaged.

\section{REFERENCES}

Longman, M. J. 1966. Explanatory Report 1-mile Geol. Map ser., K/55-7-39, Launceston. Geol. Surv. Tasm.

McDougall, I. \& LegGo, P. J. 1965. Isotopic age determinations on granitic rocks from Tasmania. J. geol. Soc. Aust., 12, 295-332.

Marshall, B., Barton, C. M., Jennings. D. J. \& Naqui, I. H. 1965. Pipers River Sheet. Geol. Surv. Tasm., 1-mile Geol. Map Ser. 8315N (K55-7-31).

Marshall, B. In press. Explanatory Report 1-mile Geol. Map Ser. K55-7-31., Pipers River. Geol. Surv. Tasm.

Williams, E. 1967. Joint Patterns at Dalrymple Hill, North-east Tasmania. Geol. Mag., 104, $240-252$.

School of ApPlied Geology,

UNIVERSITY OF NEW SOUTH WALES,

P.O. BOX 1, KeNSINGTON,

New South Wales,

Australia.

28th January, 1968.

Brian Marshall.

\section{THE SILURIAN-DEVONIAN BOUNDARY}

Sir,--In 1965, Holland presented a very comprehensive account of the problems relating to the Siluro-Devonian Boundary. He made a case for the retention of the stable and clearly defined boundary marked by the base of the Ludlow Bone Bed (as defined by White (1950) and Holland, Lawson \& Walmsley (1963)). His appreciation that many workers on the continent were at that time anxious to establish a boundary at a very much higher position in the Central European graptolitic successions probably prompted him to suggest a compromise boundary at the base of the $M$. uniformis Zone. 